\title{
Proses dan Bentuk "MeWujudnya" Kota Solo BERDASARKAN TEORI CITY SHAPED SPIRO Kostof
}

\author{
KUSUMASTUTI \\ PROGRAM STUdi PERENCANAAN WILAYAH DAN KoTA \\ FAKULTAS TEKNIK \\ UnIVERSiTAS SEBELAS MARET, SURAKARTA
}

\begin{abstract}
Teori city shaped menyebutkan bahwa pola-pola struktur ruang perkotaan mewujud melalui proses-proses sosial, ekonomi, dan politik-administratif. Proses tersebut kemudian menyampaikan makna dari arsitektur dan mewujud dalam bentuk struktur pola ruang, tata guna lahan dan karakter arsitektur bangunan yang secara keseluruhan menggambarkan citra kota.

Kota Solo adalah salah satu kota yang memiliki sejarah panjang dalam proses pembentukannya. Diawali dari Desa perdikan, Desa Sala, yang ramai dengan lalu lintas barang dari Bandar Beton di tepi Sungai Bengawan Solo sebagai bandar perdagangan di lintasan urat-nadi perdagangan Jawa Tengah dan Jawa Timur. Kemudian mewujud sebagai kota kerajaan (Kuthonegoro) setelah pusat Kerajaan Mataram dipindah dari Kartasura ke Solo. Ketika Belanda menjajah Indonesia maka Pemerintah Kolonial Belanda masuk ke dalam urusan pemerintahan Keraton Surakarta. Surakarta kemudian berkonsep spatial Kota Jawa Kolonial, yaitu perpaduan antara kota modern dengan jalan militer dan rel kereta api yang menghubungkan kota dengan hinterlandnya dengan konsep Kuthonegoro di dalam wilayah inti Keraton Surakarta. Setelah Indonesia merdeka maka Surakarta menjadi bagian dari Negara Kesatuan Republik Indonesia dalam bentuk kota. Sejarah panjang yang dilalui Kota Solo inilah yang kemudian mempengaruhi wujud arsitektur Kota Solo.
\end{abstract}

Keywords: proses, bentuk, kota, teori

\section{PENGERTIAN KOTA}

Teori "Urban Form" Kostof yang dihubungkan dengan buku "Good City Form" Kevin Lynch,membagi model normative kota menjadi tiga kategori, yaitu:

1. The cosmic model atau holy city adalah rencana kota yang diterjemahkan dari jagad dan tuhan/dewa. Karakteristik model ini adalah keberadaan axis yang monumental, adanya tembok keliling dan pintu gerbang, keberadaan landmark yang dominan, menggunakan pola grid yang teratur dan hierakhi dalam organisasi ruang perkotaan.

2. The practical model adalah kota yang bersifat faktual dan fungsional. Tersusun atas beberapa bagian yang berdiri sendiri namun saling berhubungan satu sama lain seperti sebuah mesin sehingga terkesan "dingin."

3. The organic model adalah kota yang memiliki batas wilayah dan ukuran optimum, bersifat kohesif, tidak terpisah- pisah menyangkut struktur internalnya dan memiliki perilaku yang selalu mencari keseimbangan dalam perubahan yang terjadi secara alamiah. Model kota ini mengibaratkan kota sebagai makhluk hidup.

Sementara itu Conzen menggunakan ilmu geografi untuk mendefinisikan kota bahwa kota terdiri dari tiga elemen, yaitu sistem jaringan jalan, pola tata guna lahan yang di dalamnya terdapat pembagian kapling tanah dan tata letak bangunan, serta tekstur masa bangunan.

Di sisi lain, Kostof membagi kota berdasarkan pengertian kota yang tidak direncanakan (unplanned city), yaitu kota yang terjadi secara spontan, bentuknya tidak teratur dan tidak geometrik, serta kota yang direncanakan (planned city), yaitu kota yang berbentuk grid sehingga mudah untuk pengaturannya. 


\section{BENTUK KOTA}

Pola Organik

Kota yang terbentuk dari beberapa desa akibat adanya perubahan, yang mengikat antara hak individu dengan kehendak umum dan membentuk satu unit organik untuk hidup bersama. Kota model ini biasanya mensimbolkan power, yaitu kota yang melayani kebutuhan penguasa. Bentuk ortogonal (segi empat) membentuk struktur keruangan yang mencerminkan hierarkhi yang tidak bisa diubah serta membentuk struktur ruang kota yang terdiri dari kawasan istana, kawasan administrasi, keagamaan dan perumahan berbasis kelas sosial.

\section{Pola Grid}

Kota yang dibentuk dengan pola grid dimaksudkan untuk membentuk permukiman yang teratur, untuk kepentingan penguasaan militer, serta untuk mengakomodasi kebutuhan militer, perdagangan kapitalis dan kota industri. Beberapa hal yang harus diperhatikan pada kota berpola grid adalah:

\section{The city as diagram}

Merupakan kota benteng berbentuk polygon dengan sembilan sisi dinding dan terdapat piazza berbentuk heksagonal di tengahnya.

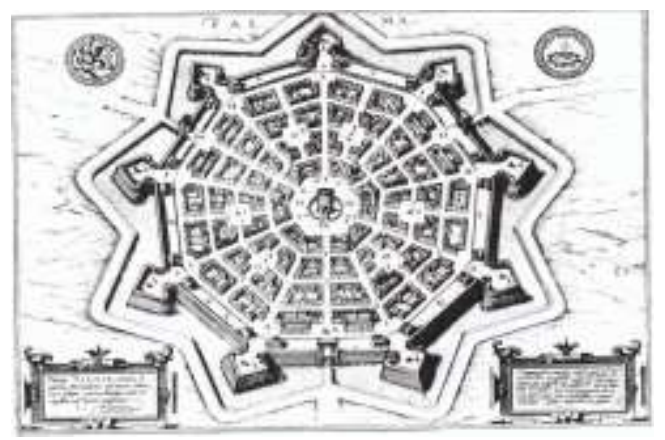

Gambar 1: Contoh Pola Grid pada Kota

Palmanova, Italy, Dirancang Pertama

Tahun 1593

(Sumber: Kostof, 1991)

2. Kota utopia dan kota ideal

Kota utopia bentuknya tidak harus sebuah kota karena kota jenis ini tidak memiliki spesifikasi yang berhubungan dengan suatu tempat dan aturan untuk ketentuan fisiknya tidak jelas. Sedangkan kota ideal adalah kota yang keberadaannya untuk menjelaskan posisi kekuasaan seorang penguasa, dimana wilayah kekuasaannya ditunjukkan dalam bentuk lingkaran yang dibatasi secara geografis dan budaya.

\section{Holy City}

Proses pembentukan holy city terjadi pada masa pra-industri dengan menggunakan agama sebagai patokannya, yaitu tempat asal usul suatu agama dan tempat raja mengelaborasi kekuasaannya dengan gagasan kosmologi. Berbagai simbol Tuhan atau dewa tergambar jelas dalam struktur ruang kotanya seperti istana, mahkota serta axis utama kota.

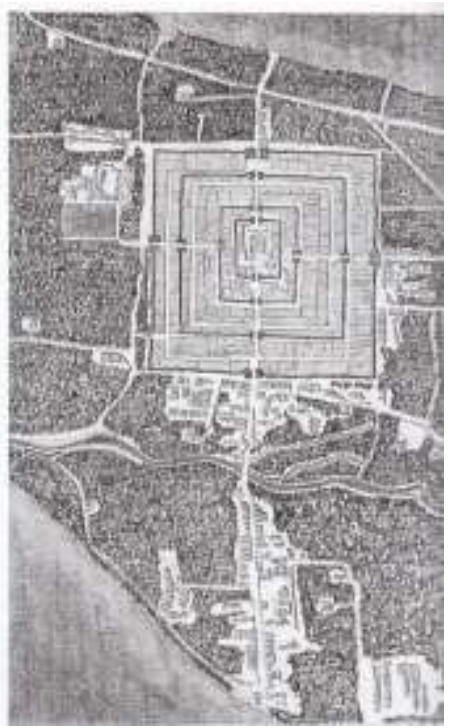

Gambar 2: Contoh Holy City di Srirangan, India Selatan a. Site Plan

b. Pusat Kota Suci dan Peta Lokasi Kota

c. Area Ziarah di Sungai Cauvery (Sumber: Kostof, 1991)

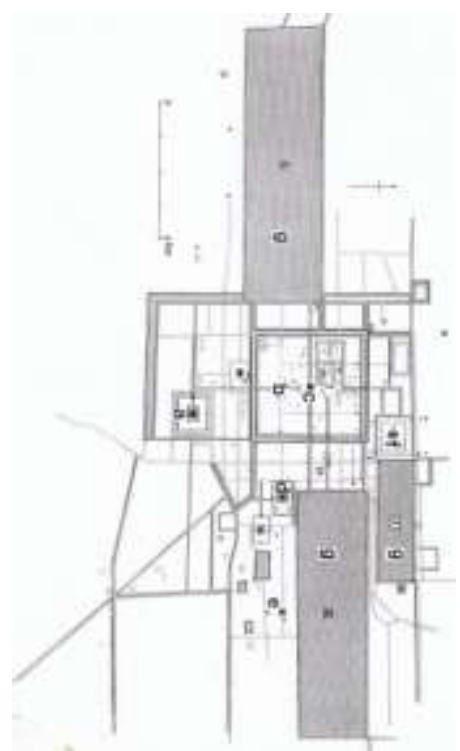

Gambar 3: Contoh Holy City di Angkor Thom, Kamboja

a. Angkor Wat

b. Angkor Thom

c. Banyon Sanctuary

d. Candi Ta Prohm

e. Candi Pre Rup

f. Candi Preah Khan

g. Tandon Air

(Sumber: Kostof, 1991) 
4. Diagram politik

a. Sistem linier

Kota dengan sistem ini umumnya menggunakan unsur sumbu dan lingkaran. Konsep sumbu untuk menjelaskan hubungan antara mikrokosmos dengan akherat/surga seperti konsep kota suci. Sedangkan konsep lingkaran digunakan untuk menunjukkan posisi penguasa dengan pasukan militernya seperti konsep ideal cityyang ditunjukkan oleh keberadaan candi, gereja atau masjid yang selalu dekat dengan kekuasaan.
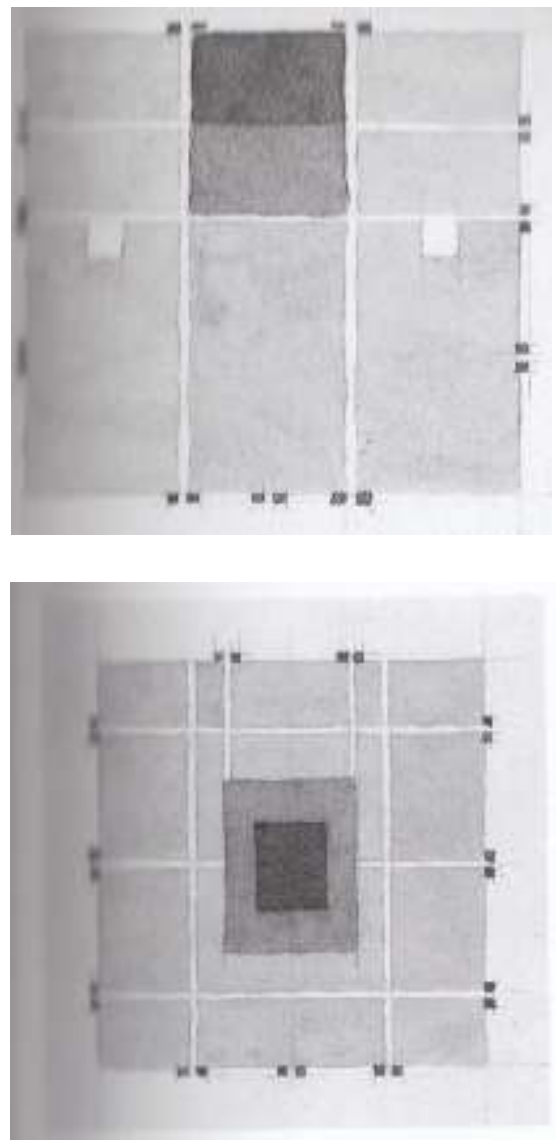

Gambar 4: Contoh Sistem Linier pada Dua Skema Kuno Ibukota Imperium Cina: Istana di Pusat Mundur Ke Arah Utara pada Kasus Chang'an (kiri) dan di tengah kota pada kota Beijing (kanan) (Sumber: Kostof, 1991)

b. Sistem terpusat

Sistem kota ini menggunakan pusat sebagai sumber kekuasaan kemudian membagi-bagi kekuasaannya seiring dengan pertumbuhan dan perkembangan kotanya.
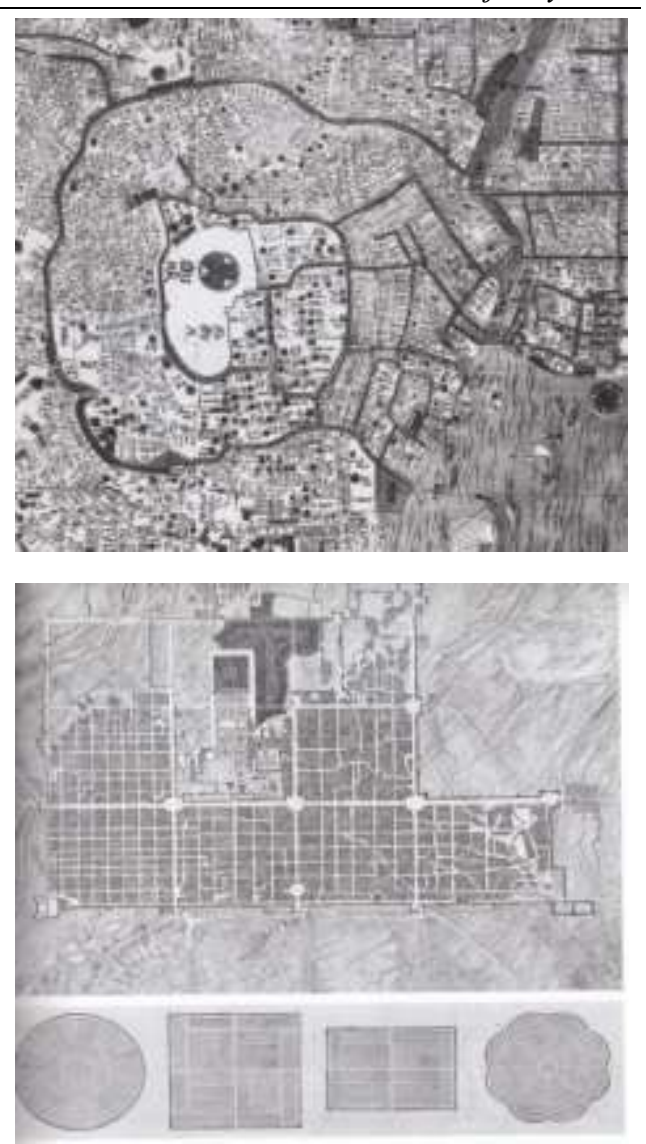

Gambar 5: Contoh Pola Kota Memusat (Concentric Organization) (Sumber: Kostof, 1991)

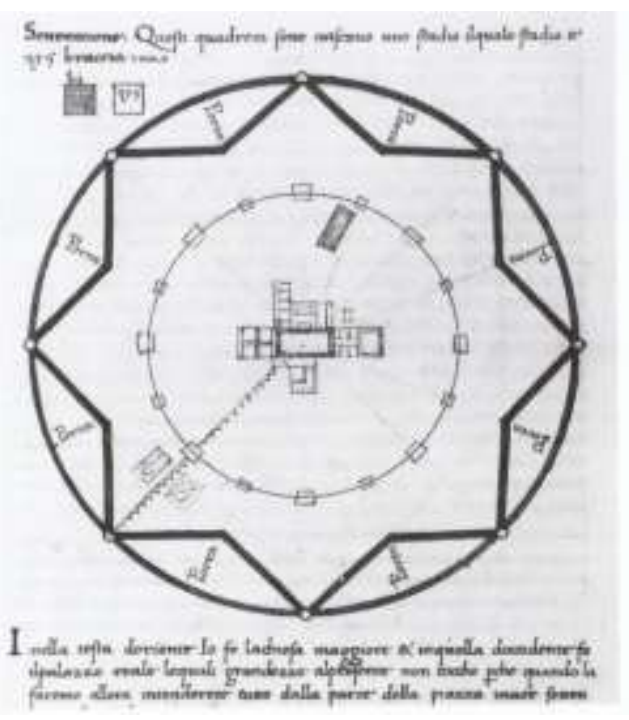

Gambar 6: Contoh Pola Kota Radial Organisasi (Sumber: Kostof, 1991) 


\section{Diagram Fungsional}

a. Logika pertahanan

Kota dibentuk untuk tujuan pertahanan, diwujudkan dalam bentuk sistem jaringan jalan radial, "bastion" pada ujung luarnya dan ruang publik pada posisi pusatnya.
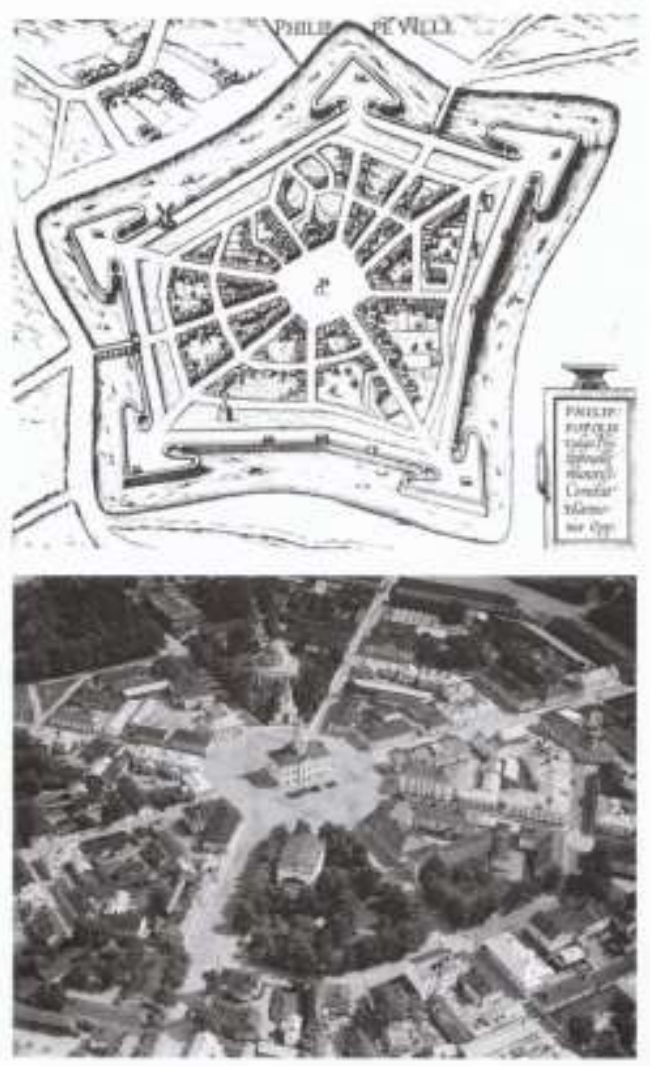

Gambar 7: Contoh Pola Kota dengan

Logika Pertahanan

(Sumber: Kostof, 1991)

b. Traffic dan radial concentricity

Kota ini dibentuk dengan menarik seluruh unsur kota ke pusat kota, sepertihalnya kota-kota dagang pada abad pertengahan. Pada perkembangannya bentuk ini kemudian berkolaborasi dengan bentuk diagonal Baroque hingga membentuk kota radial, dimana pusat kota dipecah-pecah menjadi distrik-distrik pusat bisnis yang dihubungkan dengan jaringan tranportasi.

\section{The Grand Manner}

Grand Manner adalah suatu bentuk perencanaan kota yang lebih kompleks dengan biaya besar. Umumnya, di belakang Grand Manner terdapat kekuasaan besar, pemerintahan yang sentralistis dan sumber daya yang kuat. Wujud dari Grand Manner umumnya adalah jalan yang besar dan lurus, ruang publik kota yang luas dengan pembatas yang seragam dan bangunan-bangunan publik menempati lokasi masing-masing sesuai dengan fungsinya. Wujud ruang kota ini direncanakan untuk menunjang seluruh aktivitas masyarakatnya (fungsional) seperti untuk kegiatan pawai dan karnaval yang kesemuannya ditujukan untuk mewakili penguasa.Wujud ruang kota ini menjadi penutup bagi kehidupan masyarakat yang secara umum biasa saja sehingga masyarakat selalu siap untuk berperan pada seluruh kegiatan yang diselenggarakan oleh penguasanya.

Grand Manner merupakan model perencanaan kota yang tidak menggunakan master plan tetapi mengalir berdasarkan respon generasi per generasi. Bentuk kota ditetapkan lewat unsur jalan utama (thoroughfares) dan open space yang diciptakan menerus (bersambungan tanpa diputus) sepanjang bentang kota. Skema ini tidak dibangun serempak sekali jadi, tetapi dibangun setahap demi setahap, secara empiris, tanpa teori yang kaku.

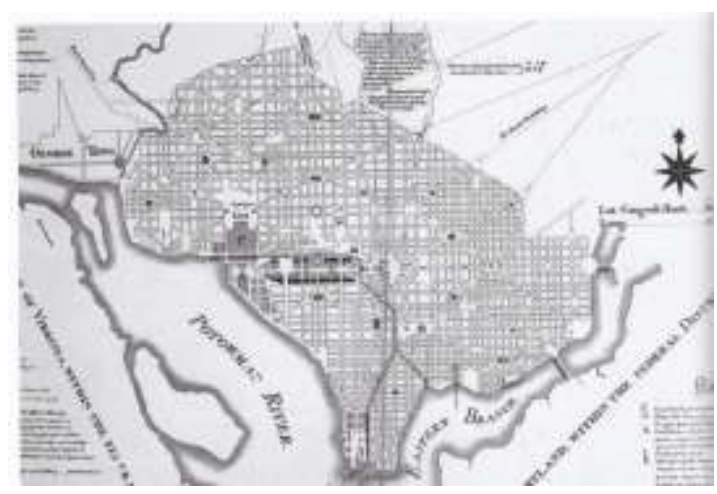

Gambar 8: Contoh Pola Kota Grand Manner (Rencana Kota Washington) (Sumber: Kostof, 1991) 
PROSES DAN BENTUK MEWUJUDNYA KOTA SOLO

Kota Solo adalah salah satu kota tua di Indonesia yang menyimpan berbagai peninggalan kebudayaan dari bermacam suku bangsa. Peninggalan pada masa sejarah, seperti keraton maupun bangunan-bangunan kuno lainnya masih dapat dijumpai di berbagai sudut Kota Solo. Pada perkembangannya, pertumbuhan Kota Solo dapat dilihat dari tiga tipe pertumbuhan, yaitu:

\section{Kota Solo sebagai Kota Kerajaan (Tradisional)}

Dalam sejarahnya, Kota Solo pernah menjadi pusat Kerajaan Mataram. Sejak berdirinya, pusat Kerajaan Mataram telah mengalami beberapa kali perpindahan, bermula dari Kerajaan Demak kemudian pindah ke Pajang, Kotagede, Plered, Kartasura dam terakhir pindah ke Desa Solo.

Pada awal pembentukan kota Kerajaan Mataram, sepertihalnya holy city, agama menjadi salah satu patokan dalam penataan kota, dalam hal ini adalah konsep atau paham kosmologi. Berdasarkan paham kosmologi, kraton merupakan pusat kerajaan dan simbol kekuasaan Raja yang berkuasa (lihat gambar 9). Sedangkan simbol raja sebagai wakil tuhan (kalifatullah) direpresentasikan dengan keberadaan Masjid Agung. Sementara itu, keberadaan pasar menjadi simbol kemakmuran. Pasar merupakan pusat kegiatan bagi proses koleksi dan distribusi komoditi hasil bumi dan juga jasa. Diperlukan kondisi yang kondusif agar kegiatan tersebut dapat terus berlangsung, mengingat kompleksitas kegiatan yang terjadi di dalamnya yang melibatkan banyak orang dan banyak kepentingan. Jika pasar dapat terus berlangsung, berarti telah terjadi pembagian tugas, artinya pula kontrol atau pengawasan atas proses (administrasi) dalam pasar sudah berjalan dengan baik.

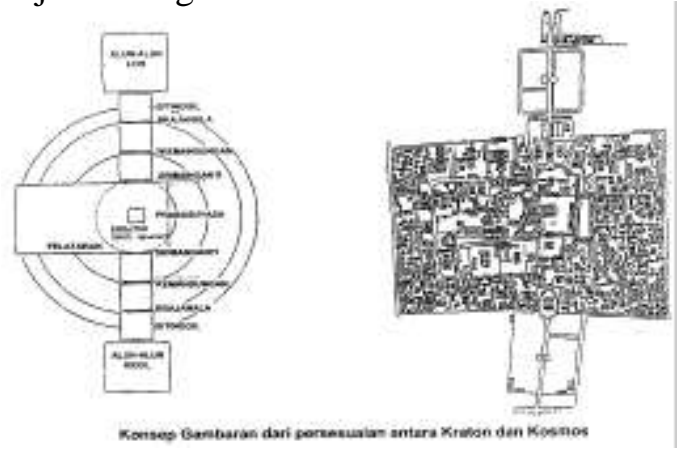

Gambar 9: Konsep dan Gambaran dari Penyesuaian antara Kraton dan Kosmos

(Sumber: Behrend, 1982)
Di sisi lain, kota Kerajaan Mataram awal juga menunjukkan gambaran sebuah kota ideal, yaitu kota untuk menunjukkan representasi penguasa yang diwujudkan dalam bentuk lingkaran dibatasi secara geografis dan budaya. Kota ideal pada masa Kerajaan Mataram mulai mewujud pada masa kekuasaan Sultan Agung, raja dari dinasti ketiga Kerajaan Mataram. Sultan Agung memilah wilayah Kerajaan Mataram secara konsentrik mulai dari kuthogoro sebagai permukiman penguasa, negaragung sebagai tanah lungguh para pangeran dan petinggi, monconegoro sebagai wilayah para bupati, dan pasisiran yang berada pada lapis paling luar.

Tata ruang dan struktur geografis wilayah kerajaan, dalam konsep kekuasaan Jawa, mencerminkan pancaran kekuasaan raja. Martabat dan kekuasaan raja akan memancar dari titik sentral yang terpusat pada kratonnya. Dari tipologi struktur geopolitik yang ada pada kerajaan-kerajaan Jawa, ada batas-batas jelas yang telah ditetapkan bagi lingkup pengaruh raja atau pusat kerajaan. Batas ini yang kemudian berkembang seiring dengan menurunnya pengaruh dan kekuasaan pusat. Pada konsep kekuasaan geopolitik Jawa feodal tradisional, kuthorojo dan kuthogoro menjadi pusat yang dikelilingi oleh wilayah yang disebut nagaragung atau negara agung. Daerah yang memperoleh status negaragung ini terletak dalam bentuk lingkaran di sekitar kuthogoro dan menjadi daerah wewenang para kerabat dan pejabat istana (sentono dan noroprojo). Pada batas luar negaragung terdapat daerah yang disebut dengan istilah monconegoro atau daerah luar atau pinggiran. Di luar daerah monconegoro, terletak wilayah yang disebut joborangkah atau di luar batas. Pada lingkaran paling luar terletak daerah pasisiran atau pantai utara dan daerah seberang lautan yang merupakan daerah taklukan atau jajahan dari penguasa di pusat kerajaan. Kesatuan wilayah tersebut bukan hanya tergantung pada integrasi politik dan ekonomi yang ditegakkan oleh raja, seperti halnya pada raja-raja feodal lainnya di Indonesia (seperti Banten, Cirebon dan Sumatra Timur), namun pada raja-raja Jawa, kesatuan juga tergantung pada kekuatan mistik kerajaan dari lapisan tertinggi di kraton hingga sampai lapisan terbawah di desa-desa (Gesick, 1989).

Tatanan kosmologi kota kerajaan di Kota Solo mencitrakan dunia kosmos yang menurut Behrend (dalam Solo Heritage Society, 2004) mengikuti pola lingkaran- 
lingkaran konsentris yang berpusat di Prabasuyasa sebagai Dalem (rumah) raja. Setiap lapis lingkaran diwujudkan sebagai halaman-halaman kraton yang dibatasi oleh regol/kori/pintu gerbang yang dimulai dari lapis terdalam Praba suyasa sampai Srimanganti, berikutnya Kamandungan, kemudian Brajanala, dan terakhir Sitinggil.

Sementara itu, pandangan pola Kraton Jawa yang linear menurut sumbu utara-selatan dikemukakan sebagai berikut oleh Brongtodiningrat (1978), bahwa tata fisik kraton dan wilayah penghubungnya membentuk kerangka kota dengan filosofi kehidupan jagad alit yang merupakan representasi dari jagad ageng, dimana jagad ageng menceritakan sangkan paraning manungsa dan jagad alit mendeskripsikan sangkan paraning dumadi. Menurut Morin (2014), jagad ageng mengurai tentang hidup dan kehidupan masyarakat dengan pemimpin yang senantiasa menjadikan hati nurani rakyat untuk mewujudkan kesejahteraan masyarakat yang dilandasi oleh kepercayaan kepada Tuhan. Sedangkan jagad alit mengurai proses awalakhir hidup dan kehidupan manusia dengan perilakunya yang lurus sehingga dapat memahami hakekat hidup dan kehidupan manusia.

BerdasarkanTeori Kostof, bentuk organisasi ruang kota pusat kerajaan Kraton Jawa menunjukkan karakteristik model Holy City, yaitu:

1. Axis monumental, yang dalam konsep Kraton Jawa diwujudkand alam konsep Kiblat Papat Lima Pancer.

2. Tembok keliling dan pintu gerbang, yang dalam konsep Kraton Jawa diwujudkan dalam bentuk beteng dan jagang.

3. Landmark yang dominan, yang dalam konsep Kraton Jawa diwujudkan dalam bentuk alun-alun, masjid, kraton dan pasar.

4. Pola grid yang teratur danb erhierarkhi, yang dalam konsep Kraton Jawa diwujudkan dalam bentuk struktur ruang kota kosmologi yang terhierarkhi berdasarkan struktur sosial.

1 Cepuri adalah tembok tinggi yang mengelilingi kompleks kraton, sementara itu Baluwarti adalah beteng yang mengelilingi kompleks kraton beserta
Untuk lebih jelasnya, organisasi ruang kota pusat kerajaan (kuthanegoro) Kraton Jawa terdiri atas:

1) Komponen-komponen Tataruang Kota Pusat Pemerintahan

Komponen-komponen kota pusat pemerintahan kerajaan dengan konsep Kosmologi Jawa,tataletaknya secara fisik selalu berkaitan antara satu dengan yang lainnya yaitu(a) Beteng dan jagang; (b) Cepuri dan Baluwarti ${ }^{1}$; (c) Alun-alun, Kraton, Masjid Agung dan Pasar. Keterkaitan ini bersifat fungsional dan simbolik. Sementaraitu, keberadaan komponen-komponen yang dekat dengan kraton ditafsirkan sebagai lambang kekuasaan raja atas kehidupan filosofisreligius, politis, ekonomis dan kultural sesuai dengan kedudukannya sebagai Kalifatullah.

2) Arah Orientasi KomponenTata-ruang Kota Pusat Pemerintahan

Arah orientasi memegang peranan penting dalam kajian tentang tataruang kota di Jawa. Dalamtata-ruangkota di Jawa, ,kraton, masjid dan pasar merupakan civic centre yang letaknya berada di tengah-tengah kota. Jalan utama yang membujur arah Utara-Selatan dan atau berasal dari Alun-alun tampaknya merupakan awalmula aksis Utara-Selatan. Pola tata ruang Civic centre tersebut menunjukkan gejala bahwa konsep tersebut sudah muncul sejak berabad-abad lalu danmasih menunjukkan kesinambungannya meskipun dalam masa Mataram-Islam sudah kabur sebagai akibat dari masuknya pengaruh Islam. Di Kraton Surakarta, konsep ini dikenal dengan nama Kiblat Papat lima Pancer,yaitu keselarasan antara dunia manusia (mikrokosmos) dengan jagad raya (makrokosmos) (lihat gambar 10).

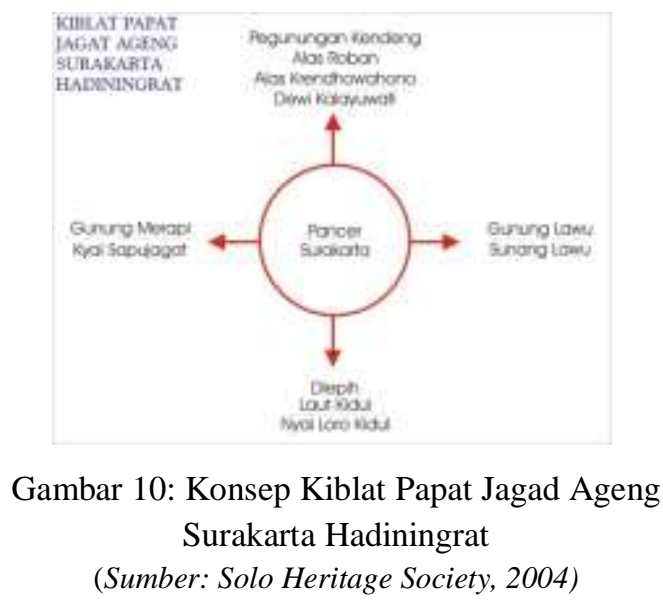

kelengkapannya serta hunian-hunian disekitarnya. Jadi Cepuri ada didalam Baluwarti yaitu kompleks tempat tinggal raja. 
Pada masa Pra-Islam, ibukota kerajaan merupakan salah satu unsur dalam dunia manusia yang diatur supaya sesuai dengan pengaturan jagad raya, sehingga sisi-sisinya menghadap padaempat arah mata angin, dan ditengahnya terdapat sebuah Kuil sebagai lambang Celestial Mountain (Geldern dalam Inajati, 2000). Pada masa Mataram-Islam, agaknya upaya untuk menyelaraskan diri dengan jagad raya terwujud dalam konsep Mancapat dan Manca lima atau seringd isebut sistem empat-lima, antara lain mengatur penempatan desa dalam ruang yang berbentuk segiempat, dimana empat desa terletak pada empat penjuru mata angin utama dan sebuah desa berada di pusatnya.

\section{3) Pola Tata Ruang Kota Pusat Kerajaan}

Struktur tataruang Kota Solo sebagai ibukota kerajaan atau kuthanegara sangat dipengaruhi olehtradisi keagamaan Hindu maupun Budha. Hierarkhi dan hubungan antar ruang-ruangnya sangat dipengaruhi oleh upacara ritual dan simbolsimbolnya.Sementarai tu, tata-ruang Kota Solo sangat berhubungan dengan struktur sosial masyarakat Jawa.

Dalam struktur tata ruang Kota Solo, Raja bertempat tinggal di dalam kraton (istana) yang terletak dipusat kota kerajaandan dikelilingi oleh para pemuka agama (ulama) dan para pemimpin kerajaan (sentono dalem).Lingkaran berikutnya adalah abdi dalem (pelayan), prajurit (tentara), dan para seniman (pengrajin). Sementara itu di luar kota tinggallah para pedagang dan petani. Hal itu menggambarkan struktur dari kosmos bahwa Dewa/Tuhan ada di tengah-tengah dikelilingi rakyat kebanyakan atau rakyat jelata (lihat gambar 11).

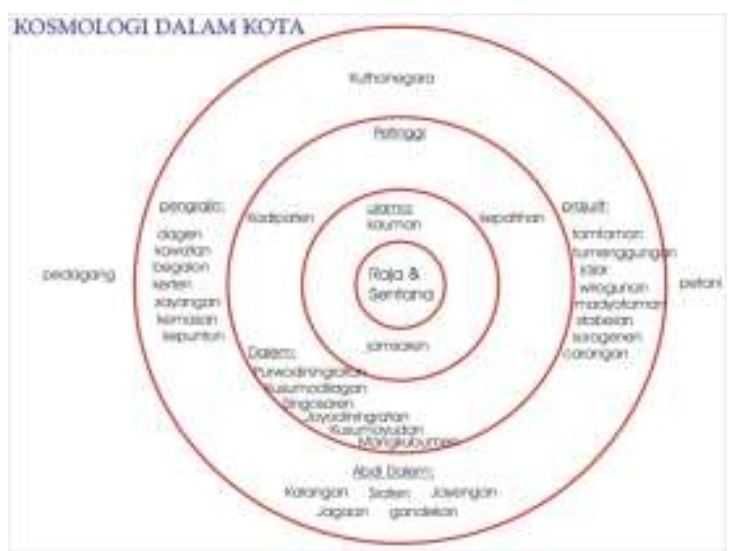

Gambar 11: Konsep Kosmologi dalam Kota Solo (Sumber: Solo Heritage Society, 2004)
Untuk memenuhi kebutuhan akan tempat tinggal bagi para kerabat dan pejabat kraton, maka dilakukanlah pembangunan kompleks perumahan. Salah satunya adalah tempat tingga Patih Dalem yang merupakan pejabat tertinggi dalam struktur pemerintahan kraton setelah raja.Patih dalem memperoleh lokasi di sebelah barat laut kraton. Tempat tinggal Patih Dalem disebut dengan Kepatihan, dibangun sebagai tempat tinggal patih bersama keluarganya.

Sementara itu, para bangsawan yang merupakan pejabat dan saudara Raja, membangun tempat tinggalnya sekitar kraton. Umumnya mereka menghuni kampung yang kemudian diberi nama sesuai dengan pangkat dan jabatan yang disandangnya. Para bangsawan ini memiliki wewenang otonom di dalam wilayah tempat tinggalnya. Dengan statusnya sebagai patuh atas tanah-tanah apanage, para bangsawan ini juga berhak menerima para abdi dan kawula di tanah-tanah lungguh pada hari pisowanan tertentu untuk menyetorkan hasil bumi tanah-tanahnya. Menurut Suhartono (1991), tanah apanage adalah tanah lungguh, tanah jabatan sementara sebagai upah/ gaji seorang priyayi/ bangsawan. Tanah ini dapat dieksploitasi untuk menghasilkan pajak berupa uang, barang dan tenaga kerja.

\section{Kota Solo sebagai Kota Kolonial}

Kota-kota yang dikembangkan oleh VOC di Indonesia sering disebutdengan 'Founded Settlement' atau cikal bakal permukiman kolonial. Belanda selalu memiliki tata ruang dan elemen-elemen yang menganut pedoman dan petunjuk teknis yang dikendalikan di Netherland serta diawasi oleh Gubernur Jendral, Residen dan para ahli teknik. Hal ini berhubungan dengan konsep kolonialisasi, dimana terjadi hubungan dominance-dependence (hubungan dominasi ketergantungan). Hubungan ini menunjukkan ketergantungan masyarakat yang dijajah sebagai akibat dari penekanan fungsi militer dan administrasi pada daerah jajahannya.

Karakteristik yang paling penting dari kota Kolonial adalah adanya pembagian tripartit dalam kota, yaitu kota pribumi, kota militer dan kota sipil yang ditunjukkan dengan keberadaan 3 (tiga) jenis bangunan besar yaitu:

a) Bangunan militer, meliputi benteng, dinding pertahanan dan kanal

b) Bangunan-bangunan sipil, meliputi tanggul dan jembatan 
c) Bangunan fasilitas perkotaan, meliputi jalan yang memisahkan blok bangunan dan petak-petak perumahan.

Berdasarkan Teori Kostof, Founded Settlement ini menunjukkan bahwa struktur ruang Kota Kolonial layaknya sebuah mesin.

Sementara itu, perencanaan dan perancangan permukiman Kota Kolonial memiliki tiga unsur pokok, yaitu:

a. Lokasi

b. Alasan keberadaan permukiman

c. Elemen pengaruh desain (filosofi desain atau Leitmotiv)

Sehubungan dengan lokasi, pantai adalah suatu pilihan yang pasti (absolut) dalam perencanaan dan perancangan permukiman Kota Kolonial. Berdasarkan fakta, semua lokasi permukiman pilihan berada di tepipantai atau ditepi sungai. Hal ini sesuai dengan jiwa bangsa Belanda sebagai bangsa pelaut. Negerinya dianggap sebagaisebuah delta sungai besar yang memberikan sumbangan terhadap penemuan dan pendudukan suatu wilayah melalui laut.

Permukiman ditepi pantai/dimuara sungai menunjukkan adanya kemampuan menguasai dan mengawasi setiap kapal yang datang, terutama kapal lawan.Tujuan utama Belanda datang ke Indonesia (awalnya) adalah berdagang, ketika kemudian muncul keinginan untuk menjajah maka lokasi pusat permukiman, administrasi dan militernya dipilih yang memungkinkan mereka berpeluang untuk mengeksploitasi hasil bumi dari hinterland sebagai komoditi perdagangan eksport. Komoditi ini kemudian di kumpulkan, diproses/diolah dan didistribusikan baik ke Asia atau ke Eropa.

Elemen pengarah disain (leitmotiv) biasanya adalah elemen fisik pada lay-out permukiman, menjelaskan mengapa lokasi ditepi pantai/sungai dipilih dan menjelaskan latar belakang pemikiran pembangunan yang dilakukan. Kadang elemen itu tampak nyata dan menyatu dalam perancangan dan pembangunannya, kadang elemen tersebut hanya muncul sebagai simbol yang menggambarkan ide dasarnya. Kadang elemen itu diambil dari unsur alam lingkungan yang dimodifikasi dengan bantuan pekerjaan teknik sipil sehingga mewujudkan satu bentuk pertahanan dan cara mengelola wilayah (the management of site). Garis panjang dari
Dimana elemen-elemen ruang kota yang dibentuk memiliki hubungan satu dengan lain secara fungsional, meskipun dari luar tampak berdiri sendiri. Kota dengan tipologi seperti ini disebut dengan model Practical City, yaitu kota yang bersifat faktual dan fungsional.

hinterland, melewati permukiman sampai ke bandar/pelabuhan dan laut ke Patria (negeri Belanda), mencerminkan proses pengumpulan, penimbunan/penyimpanan, dan distribusi, merupakan gambaran yang paling penting dari maksud tujuan Belanda menjajah Indonesia. Wujud dari garis panjang ini dalam tata ruang kota dapat bermacam-macam, contohnya sebuah jalan dengan alun-alun, atau suatu infrastruktur yang dominan, atau sebuah elemen yang diletakkan di tengah-tengah permukiman. Semuanya itu menggambarkan ide dasar dalam perencanaan dan perancangan permukiman Belanda (lihat gambar 12).

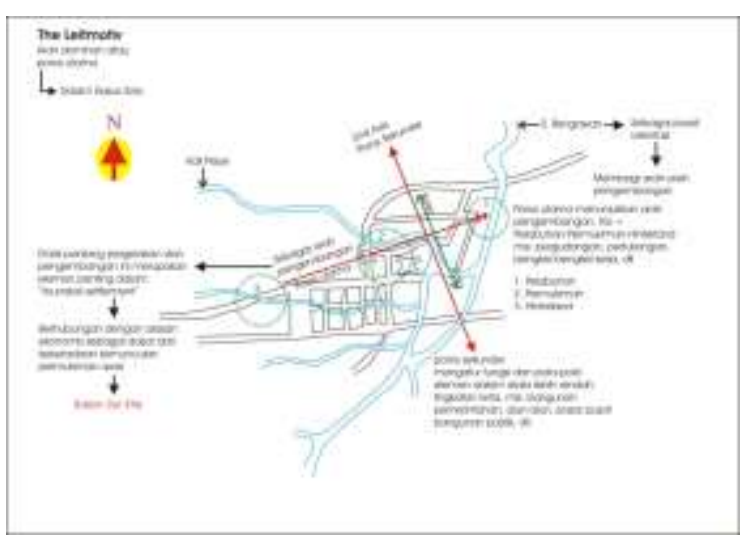

Gambar 12: Leitmotiv Kota Kolonial di Kota Solo (Sumber: Solo Heritage Society, 2004)

\section{Keterangan :}

Pada awalnya, poros utama Kota Solo adalah Kali Pepe yang merupakan anak Sungai Bengawan Solo. Namun ketika peran sungai-sungai tersebut mulai menyusut dan digantikan dengan jalan darat, yaitu jalan militer yang dibangun Daendels (sekarang Jalan Slamet Riyadi) dan jalur jalan kereta api yang diterapkan di Solo pada tahun 1870-an, poros utama kota menjadi berubah. Jalan militer dalam perkembangan selanjutnya menjadi poros utama, dengan jalan-jalan kereta api, yang dilengkapi dengan segala kelengkapan stasiunnya antara lain gudang, bengkel dan sebagainya. 


\section{Kota Solo sebagai Kota Modern}

Pada tahun 1900, Kota Solo telah menjadi kota multiras, dengan dominasi suku Jawa. Administrasi di bawah Kraton Kasunanan Surakarta dibagi menjadi 5 kapanewon (sub distrik), yaitu Kutho, Laweyan, Pasar Kliwon, Serengan dan Jebres. Sementara administrasi di bawah Mangkunegaran hanya terdiri dari satu kawedanan. Kawedanan Gunung Salebeting Kitha dengan 2 kapanewon, yaitu Kampung Lor dan Kampung Kidul. Pada sub distrik Kampung Lor terdapat kampung Setabelan, Margareja, dan Pasar Legi, sementara Kampung Keprabon, Timuran, Ketelan dan Pethetan termasuk dalam sub distrik Kampung Kidul.Sementaraitu, adminstrasi berdasar pemerintah kolonial dibagi menjadi tiga wijk pada tahun 1915 yang menjadi tanggungjawab dari kepala tiap-tiap wijk tersebut. Wijk-wijk tersebut adalah wijk Tenggara, Timur Laut, Barat, sementara wijk untuk golongan Cina diberikan tersendiri dengan kepala wijknya ditunjuk oleh pemerintah colonial, yaitu di Jebres, Mesen, Kepatihan, Balapan dan beberapa rumah di sepanjang jalan di Kasunanan. Orang Arab juga tinggal di wijk khusus, yaitu Pasar Kliwon. Wijk merupakan sebutan bagi wilayah permukiman berdasarkan etnis yang dibentuk oleh Pemerintah Kolonial Belanda.

Perubahan terbesar pada tahun 1900-an ini adalah dibangunnya berbagai utilitas kota yang modern, yaitu jaringan listrik padatahun 1902 oleh Solosche Electriciteits Maatschappij atau S.E.M., jaringan air bersih padatahun 1926 oleh N.V. Hoogdruk Waterleiding atau N.V.H.W., jaringan KA dan trem padatahun 1905 oleh Staats Spoorwagen atau S.S. dan Nederlandsch Indische Spoorwagen atau N.I.S. dan pembangunan jembatan antar kota yang melintasi Bengawan Solo, yaitu Jembatan Jurug yang menuju Karanganyar dan Jembatan Bacem yang menuju Sukoharjo padatahun 1915. Di sisi lain, penduduk yang mulai ramai dan padat ditambah fasilitas hiburan dan olah raga, yang umumnya baru pertama dibangun di Indosesia saat itu, yaitu gedung bioskop, gedong pertunjukan Jawa (wayang, kethoprak, kerawitan), gedung pertemuan, stadion sepak bola, lapangan berkuda, taman-taman kota dan stasiun radio.

Setelah Indonesia merdeka pada tahun 1945, terjadipergolakan politik dan sosial, serta perubahan lingkungan alam yang berpengaruh buruk kepada ruang kota. Pada tahun 1948 terjadi peristiwa Clash II, yang terkenal dengan politik bumi hangus, sehingga banyak bangunan di Solo yang hancur. Pada tahun 1966 terjadi banjir besar di Solo akibat meluapnya Sungai Bengawan Solo sehingga separoh Kota Solo tenggelam. Pada tahun 1970-an, terjadi bermunculannya kegiatan dan bangunan industri di sekitar Bengawan Solo, yaitu Palur dan sekitarnya, dimana salah satu dampaknya adalah pencemaran Sungai Bengawan Solo karena sebagian industri tersebut membuang limbah industrinya ke Sungai Bengawan Solo.

Sementara itu, pada tahun 1980-an, setelah terjadi urbanisasi dan industrialisasi, Kota Solo mengalami urban sprawl (pemekaran kota), baik di sisi utara, timur, selatan dan barat. Pembangunan perumahan berupa real-estate, perumnas dan komplek hunian baru mulai bermunculan dipinggiran Kota Solo. Pada pusat kotanya, terutama daerah CBD, berkembang pemaksaan bentuk joglo (penjogloan), meskipun mempunyai tipe berlantai banyak. Pada sisi yang lain, Kota Solo yang semula hanya mempunyai fasilitas pendidikan sampai SMA, kini mulai dibangun fasilitas untuk jenjang pendidikan yang lebih tinggi, yaitu perguruan tinggi. Pada akhir tahun 1980-an, pemerintah mencanangkan program Paket November 1988, yang berdampak pada menjamurnya bank-bank swasta di Kota Solo. Pada tahun 1990-an, setelah pemerintah mencanangkan program Paket Juli 1993 (eksploitasi wisata), maka banyak bangunan hotel bermunculan, melengkapi perkantoran dan perdagangan yang telah lebih dahulu berdiri. Pada tahun 1998, terjadi peristiwa kerusuhan massal yang menyebabkan bangunan-bangunan hangus dan hancur, sebagai dampak akibat trauma kerusuhan tersebut, di dalam kota Solo muncul modelmodel rumah yang berarsitektur seperti "benteng" atau bangunan dengan tampilan wajah tertutup dengan tembok massif atau berjendela kaca dengan teralis besi baja. Setelah mengalami periode-periode sulit dalam sejarah perkembangan dan pertumbuhan kota akibat adanya pergantian kekuasaan, maka kota modern yang terjadi di Kota Solo, berdasarkan Teori Kostof menyerupai The organic model, yaitu kota yang memiliki batas wilayah dan ukuran optimum, bersifat kohesif, tidak terpisah-pisah menyangkut struktur internalnya dan memiliki perilaku yang selalu mencari keseimbangan dalam perubahan yang terjadi secara alamiah. Sejarah panjang telah menunjukkan bahwa Kota Solo mampu 
bertahan, bahkan tumbuh dan berkembang hingga saat ini.

\section{KESIMPULAN}

Sejak berdirinya, Kota Solo mengalami tiga model perkembangan perkotaan, yaitu kota tradisional, kota kolonial dan kota modern. Disebut kota tradisional karena struktur ruang kota di atur oleh Kraton Solo yang berkuasa saat itu dengan konsep Kosmologi Jawa dimana hierarkhi sosial sangat berpengaruh dalam pengorganisasian kota. Konsep Holy city seperti Teori Kostof sangat mempengaruhi struktur ruang Kota Solo.

Sebaga kota Kolonial, Kota Solo menjadi pusat bagi kegiatan pendidikan, ekonomi dan administrasi hingga jasa pelayanan, seperti bank, industri, restoran, pertokoan, dan hotel mulai menjamur di dalam kota, begitu pula dengan kantor-kantor pemerintahan dan militer. Hal itu dilakukan untuk mendukung motif Kolonial sebagai bangsa penjajah, yaitu mengeruk kekayaan alam Indonesia dalam hal ini tanah Jawa.Founded Settlement yang merupakan model Kota Kolonial dengan pedoman dan petunjuk teknis pendirian berdasarkan konsep Kolonial diterapkan begitusaja di Kota Solo.hingga terbentuklah elemen-elemen Kota Kolonial yang tampak berdiri sendiri dengan fasilitas-fasilitasnya, namun pada dasarnya elemen-elemen ini terhubungan satu dengan lainnya secara fungsional sepertihalnya konsep Practical City dari Teori Kostof. Sedangkan sebagai kota modern, Kota Solo mengalami pasang surut dalam bidang politik karena terjadi perpindahan kekuasaan antara Pemerintah Kolonial dan Kraton Jawa pada Pemerintah Indonesia. Perubahan ini kemudian mempengaruhi struktur ruang Kota Solo akibat perubahan kekuasaan dan berkembangnya revolusi industri di dunia.Berbagai saranaprasarana kota seperti jaringan listrik, jaringan jalan, alat transportasi dan jaringan air bersih mengubah wajah Kota Solo menjadi lebih modern. Modern dalam artian masyarakat menjadi lebih mudah dalam mengakses maupun memanfaatkan fasilitas kota untuk kepentingan bersama. Lenturnya perubahan struktur Kota Solo pada masa ini sesuai dengan konsep Organic City dari Teori Kostof.

\section{DAFTAR PUSTAKA}

Adrisijanti, Inajati, 2000. Arkeologi Perkotaan Mataram Islam. Yogyakarta: Jendela.

Behrend, Timothy Earl, 1982.Kraton and Cosmos in Traditional Java.University of Wisconsin-Madison

Brongtodiningrat, K.P.H., 1978. Arti Kraton Yogyakarta. Yogyakarta: Museum Kraton Yogyakarta.

Gesick, Lorraine, 1989.Pusat, Simbol, dan Hirarki Kekuasaan, Terjemahan S. Maimoen dan Sonny Keraf. Jakarta, Yayasan Obor Indonesia.

Kostof, Spiro, The City Shaped: Urban Patterns and Meanings Through History, Bullfinch Press 1991; second edition, Thames \& Hudson, New York 1999

Kuntowijoyo.The Making of a Modern Urban Ecology: Social and Economic History of Solo, 1900-1915, dalam Lembaran Sejarah Vol 3 No 1 Tahun 2000, Jurusan Sejarah Fakultas Sastra UGM Yogyakarta

Morin, Lutse Lambert Daniel. 2014. Problematika Tugu Yogyakarta dari Aspek Fungsi dan Makna. Journal of Urban Society's Arts. Volume 14. Nomor 2. Oktober 2014: 135-148.

Nas, J.M.Peter (ed), 1986. The Indonesian Cities : Studies in Urban Development and Planning. Dordrecht : Floris Publication.

Solo Heritage Society. 2003. Sejarah Dan Morfologi Kota Konflik: Dari Periode

Kolonial-Orde Baru. (suatu hasil penelitian yang tidak/belum dipublikasikan)

Suhartono, Dr. 1991. Apanage dan Bekel, Perubahan Sosial Dipedesaan Surakarta (1830-1920). Yogyakarta: PT. Tirta Wacana Yogya. 